\title{
Rapid and simultaneous quantification of viable Escherichia coli 0157:H7 and Salmonella spp. in milk through multiplex real-time PCR
}

\author{
Baoqing Zhou, Taobo Liang, Zhongxu Zhan, Rui Liu, Fan Li, and Hengyi $\mathrm{Xu}^{1}$ \\ State Key Laboratory of Food Science and Technology, Nanchang University, Nanchang, 330047, PR China
}

\begin{abstract}
Escherichia coli O157:H7 and Salmonella spp. in milk are 2 common pathogens that cause foodborne diseases. An accurate, rapid, specific method has been developed for the simultaneous detection of viable E. coli $\mathrm{O} 157: \mathrm{H} 7$ and Salmonella spp. in milk. Two specific genes, namely, fliC from E. coli O157:H7 and invA from Salmonella spp., were selected to design primers and probes. A combined treatment containing sodium deoxycholate (SDO) and propidium monoazide (PMA) was applied to detect viable E. coli O157:H7 and Salmonella spp. only. Traditional culture methods and SDO-PMA-multiplex real-time (mRT) PCR assay were applied to determine the number of viable E. coli $\mathrm{O} 157: \mathrm{H} 7$ and Salmonella spp. in cell suspensions with different proportions of dead cells. These methods revealed consistent findings regarding the detected viable cells. The detection limit of the SDO-PMA-mRT-PCR assay reached $10^{2} \mathrm{cfu} / \mathrm{mL}$ for Salmonella spp. and $10^{2} \mathrm{cfu} / \mathrm{mL}$ for E. coli $\mathrm{O} 157: \mathrm{H} 7$ in milk. The detection limit of SDO-PMA-mRT-PCR for E. coli O157:H7 and Salmonella spp. in milk was significantly similar even in the presence of $10^{6} \mathrm{cfu} /$ $\mathrm{mL}$ of 2 nontarget bacteria. The proposed SDO-PMAmRT-PCR assay is a potential approach for the accurate and sensitive detection of viable $E$. coli $\mathrm{O} 157: \mathrm{H} 7$ and Salmonella spp. in milk.
\end{abstract}

Key words: foodborne pathogen, sodium deoxycholate, propidium monoazide, multiplex real-time PCR

\section{INTRODUCTION}

In recent years, the security of milk and its derived products has faced severe challenges (Amagliani et al., 2016; Munsi et al., 2016). As vital components in diets of many countries, milk and its derived products are easily contaminated by pathogenic bacteria at any stage from production to consumption because of their rich nutrition (Angulo et al., 2009). Data from the Cen-

Received June 20, 2017.

Accepted July 17, 2017.

${ }^{1}$ Corresponding author: kidyxu@163.com or HengyiXu@ncu.edu.cn ters for Disease Control and Prevention showed that 87 outbreaks of foodborne illnesses were attributed to pathogen-contaminated raw milk and cheese products, causing 750 illnesses and 215 hospitalizations from 2009 to 2014 (Costard et al., 2017). Among foodborne pathogens, Escherichia coli O157:H7 and Salmonella spp. have been recognized as common disease-causing agents in milk (Kim and Bhunia, 2008; Wang et al., 2016). Escherichia coli $\mathrm{O} 157: \mathrm{H} 7$ is a highly pathogenic strain that causes serious acute illnesses, such as hemolytic uremic syndrome, hemorrhagic colitis, bloody diarrhea, and long-term sequelae at low infectious doses (Karmali, 1989; Nataro and Kaper, 1998; Paton and Paton, 1998). Salmonella spp. is related to typhoid fever, septicemia, gastroenteritis, and death (AndrewsPolymenis et al., 2010). Salmonellosis also accounts for 40 to $60 \%$ of foodborne diseases in China (Ran et al., 2011). Thus, a rapid, sensitive, and accurate detection method is urgently needed to identify these 2 foodborne pathogens and consequently prevent milk contamination.

The standard method used to detect these 2 pathogens is based on culturing, but this conventional approach is laborious and time consuming (Garrido et al., 2013; Ma et al., 2014). As such, a rapid method should be developed to identify these pathogens. As a replacement of traditional culture methods, PCR is increasingly applied to sensitive and rapid detection of pathogens in food (Wang et al., 1997; Elizaquível et al., 2011). Multiplex PCR (mPCR) can also be used to discover various pathogens simultaneously in a single reaction (Lee et al., 2014). However, mPCR results are commonly obtained through agarose gel electrophoresis that easily leads to cross-contamination or yields falsepositive findings (Omiccioli et al., 2009). Multiplex real-time ( $\mathbf{m R T})$ PCR assay is a data analysis technique based on the real-time detection of a fluorescent signal integration in each reaction system, and this assay avoids time-consuming processes and laboratory crosscontamination (Mackay, 2004). Multiplex real-time PCR is designed using multiplex distinct dye-labeled probes, and this technique has been successfully applied to detect single or multiple foodborne pathogens simul- 
taneously (Wang et al., 2012; Zhang et al., 2015; Alves et al., 2016). However, general mRT-PCR assays cannot distinguish dead bacteria from viable bacteria. To determine viable bacteria distinctly from dead bacteria, Yang et al. (2011) and Li et al. (2016) proposed the use of a DNA-intercalating dye named propidium monoazide (PMA) that can effectively avoid the interference of DNA from dead cells. Although injured pathogenic bacteria lose their ability to infect hosts under normal conditions (Linder and Oliver, 1989), PMA treatment cannot completely inhibit DNA interference from some dead or injured cells with an integrated outer membrane during PCR amplification (Wang et al., 2014b). As a detergent, sodium deoxycholate (SDO) can disrupt integrated outer membranes from some dead or injured cells and change their permeability to enhance the effect of PMA treatment against injured or dead cells (Wang et al., 2015).

This study aimed to develop an mRT-PCR assay combined with SDO and PMA treatment to simultane- ously and specifically detect viable Salmonella spp. and E. coli $\mathrm{O} 157: \mathrm{H} 7$. Two fluorescence probes were designed from $i n v A$ and $f l i C$ for the specific detection of viable Salmonella spp. and E. coli O157:H7. The SDO-PMA treatment was administered before DNA was extracted for multiplex PCR amplification. Different proportions of viable and dead cells were selected to determine the effects of SDO and PMA. The feasibility of the SDO-PMA-mRT-PCR method was then evaluated in artificially spiked milk.

\section{MATERIALS AND METHODS}

\section{Bacterial Strains, Culture Medium, and Growth Conditions}

The strains used in this study are listed in Table 1. Target Salmonella spp. and E. coli O157:H7 strains and other nontarget strains were grown in Luria-Bertani (LB) medium placed in a rotary shaker at $180 \mathrm{rpm}$ and

Table 1. Target and nontarget bacteria strains used in this study and the results of the PCR

\begin{tabular}{|c|c|c|c|c|}
\hline \multirow[b]{2}{*}{ Bacteria strain } & \multirow[b]{2}{*}{ Strain ID } & \multirow[b]{2}{*}{ Source $^{1}$} & \multicolumn{2}{|c|}{ mRT-PCR positive for ${ }^{2}$} \\
\hline & & & invA & $f l i C$ \\
\hline \multirow[t]{4}{*}{ Cronobacter sakazakii $(\mathrm{n}=4)$} & 45401 & $\mathrm{CMCC}$ & - & - \\
\hline & 45402 & CMCC & - & - \\
\hline & 21919 & CICC & - & - \\
\hline & 21544 & CICC & - & - \\
\hline Salmonella Enteritidis & 13076 & ATCC & + & - \\
\hline Salmonella Anatum & 9270 & ATCC & + & - \\
\hline \multirow{2}{*}{ Salmonella Paratyphi A $(\mathrm{n}=2)$} & 9150 & ATCC & + & - \\
\hline & 40004 & JX-CDC & + & - \\
\hline \multirow[t]{2}{*}{ Salmonella Paratyphi B $(\mathrm{n}=2)$} & 40001 & JX-CDC & + & - \\
\hline & 50094 & JX-CDC & + & - \\
\hline Salmonella Typhi & 40002 & JX-CDC & + & - \\
\hline Salmonella Typhimurium & 13311 & ATCC & + & - \\
\hline Salmonella Choleraesuis & 10708 & ATCC & + & - \\
\hline \multirow[t]{3}{*}{ Bacillus cereus $(\mathrm{n}=3)$} & P20063L & JX-CDC & - & - \\
\hline & JDZ102Y & JX-CDC & - & - \\
\hline & JX0121LY & JX-CDC & - & - \\
\hline \multirow[t]{5}{*}{ Escherichia coli $\mathrm{O} 157: \mathrm{H} 7(\mathrm{n}=5)$} & 43888 & ATCC & - & + \\
\hline & 44828 & $\mathrm{CMCC}$ & - & + \\
\hline & 12900 & NCTC & - & + \\
\hline & YC0540 & / & - & + \\
\hline & XY1246 & 1 & - & + \\
\hline \multirow[t]{2}{*}{ Listeria monocytogenes $(\mathrm{n}=2)$} & 13932 & ATCC & - & - \\
\hline & 54007 & $\mathrm{CMCC}$ & - & - \\
\hline \multirow{3}{*}{ Staphylococcus aureus $(\mathrm{n}=3)$} & 26001 & CMCC & - & - \\
\hline & 26002 & $\mathrm{CMCC}$ & - & - \\
\hline & 26003 & CMCC & - & - \\
\hline Vibrio parahaemolyticus & PVPAO146 & JX-CDC & - & - \\
\hline Pseudomonas aeruginosa & 10104 & $\mathrm{CMCC}$ & - & - \\
\hline Bacillus subtilis & 63501 & CMCC & - & - \\
\hline Shigella sonnei & 25931 & ATCC & - & - \\
\hline
\end{tabular}


Table 2. Primers and probes used in the multiplex real-time PCR

\begin{tabular}{|c|c|c|c|c|}
\hline Target bacteria & $\begin{array}{l}\text { Target } \\
\text { gene }\end{array}$ & Primer and probe sequence $\left(5^{\prime} \rightarrow 3^{\prime}\right)$ & $\begin{array}{l}\text { Amplicon } \\
\text { length (bp) }\end{array}$ & Reference \\
\hline Salmonella Enteritidis & $i n v A$ & $\begin{array}{l}\text { TTCCGCAACACATAGCCAAGC } \\
\text { AATCCAACAATCCATCAGCAAGG } \\
\text { FAM-TTTCTCCCCCTCTTCATGCGTTAC-BHQ }\end{array}$ & 95 & This study \\
\hline Escherichia coli $\mathrm{O} 157: \mathrm{H} 7$ & $f l i C$ & $\begin{array}{l}\text { TCAGAATCGGAGTTAGTCCCTGT } \\
\text { GTAACGCCAACGACGGTATTT } \\
\text { HEX-CACGAATACGCTGTAAGTTGTTGT-BHQ }\end{array}$ & 127 & This study \\
\hline
\end{tabular}

$37^{\circ} \mathrm{C}$. The sterile PBS $(0.01 \mathrm{M}, \mathrm{pH} 7.4)$ was applied to suspend fresh target bacteria to obtain 10 serial dilution cell suspensions. All of the cells were grown on LB agar plates at $37^{\circ} \mathrm{C}$ for $24 \mathrm{~h}$ to enumerate the number of viable cells by culture method.

\section{Primers and Probes Used for $m R T-P C R$}

The primers and probes (Table 2) used in this study were designed using Oligo 6.0 software (http://www .oligo.net/) and synthesized by Sangon Biotech (Shanghai, China).

\section{mRT-PCR Assay}

The mRT-PCR assay was conducted in a 7900 HT fast real-time PCR system (Applied Biosystems, Foster City, CA) with a total reaction volume of $25 \mu \mathrm{L}$ containing $12.5 \mu \mathrm{L}$ of $2 \times$ TaqMan Fast qPCR Master Mix (Sangon Biotech), 0.4 $\mu \mathrm{L}$ of forward and reverse primers of $10 \mathrm{~m} M$ and $0.5 \mu \mathrm{L}$ of probes from invA $(\mathbf{P}-\boldsymbol{i n v} \boldsymbol{A}), 0.35 \mu \mathrm{L}$ of forward and reverse primers of $10 \mathrm{~m} M$ and $0.5 \mu \mathrm{L}$ of probe from $f l i C(\mathbf{P}-f l i C)$, and 2 $\mu \mathrm{L}$ of each target genomic DNA. The thermal protocol of mRT-PCR was as follows: initial denaturation of genomic DNA at $95^{\circ} \mathrm{C}$ for 2 min, followed by 30 cycles of denaturation at $95^{\circ} \mathrm{C}$ for $15 \mathrm{~s}$, and annealing at $60^{\circ} \mathrm{C}$ for $1 \mathrm{~min}$. Sterile water was used in place of the DNA templates for negative controls to ensure the absence of contamination in the wells. These experiments were performed in triplicate and analyzed using SDS 2.3 (Applied Biosystems).

\section{Optimization of SDO Concentration}

A cell suspension with injured cells was obtained for the following operations to optimize the concentration of SDO. The cell suspensions of Salmonella Enteritidis ATCC $13076\left(10^{8} \mathrm{cfu} / \mathrm{mL}\right)$ and E. coli O157:H7 ATCC $43888\left(10^{8} \mathrm{cfu} / \mathrm{mL}\right)$ were heat-treated in a water bath at $60^{\circ} \mathrm{C}$ for $5 \mathrm{~min}$ and $55^{\circ} \mathrm{C}$ for $10 \mathrm{~min}$, respectively, and immediately cooled at $4^{\circ} \mathrm{C}$ in an ice bath for 5 min (Arroyo et al., 2009). The number of viable cells in LB was determined by plate counting and centrifuged at $10,000 \times g$ for $3 \mathrm{~min}$ at room temperature. The pellet was resuspended in $500 \mu \mathrm{L}$ of PBS for SDO treatment. A $10 \%$ (wt/vol) SDO stock solution was prepared by resolving $1 \mathrm{~g}$ of SDO powder with $0.1 \%$ (wt/vol) peptone water. Two groups (6- to $500-\mu \mathrm{L}$ portions in each group) of cell suspensions, namely, refreshed viable cells and heat-treated cells with injured cells, were also prepared and treated with different quantities of $10 \%$ SDO stock solution to obtain final SDO concentrations: $0,0.01,0.05,0.08,0.1$, and $1 \%$. These suspensions were incubated in a rotary shaker at $180 \mathrm{rpm}$ and $37^{\circ} \mathrm{C}$ for 30 min and treated with PMA (Zhou et al., 2016). The DNA was extracted from cell pellets for real-time PCR assay.

\section{Optimization of PMA Concentration}

To acquire the optimal PMA concentration, dead cells with an initial concentration of $10^{7} \mathrm{cfu} / \mathrm{mL}$ were obtained by exposure to $80^{\circ} \mathrm{C}$ for $10 \mathrm{~min}$ in a water bath and were immediately immersed in ice for $5 \mathrm{~min}$. One portion of dead cells was demonstrated by plate count. The PMA (Biotium Inc., Hayward, CA) was dissolved in 20\% dimethyl sulfoxide (Sun Nuclear, São Paulo, Brazil) to reach a final concentration of $1 \mathrm{mg} / \mathrm{mL}$ and was stored at $-20^{\circ} \mathrm{C}$ in the dark. The viable and dead cell pretreatment with SDO, followed by treated PMA with final concentrations of $0,0.5,0.8,1,2,5,10$, and $15 \mu \mathrm{g} / \mathrm{mL}$, are described above. Afterward, the DNA from cell suspensions treated with PMA was extracted for PCR amplification.

\section{Evaluation of the Limit of Detection of the SDO-PMA mRT-PCR Assay}

To determine the limit of detection (LOD) of this method, the standard curve was obtained from genomic DNA extracted from pure bacterial suspension. Serial 10-fold dilutions of 2 target bacteria $\left(10^{7}\right.$ to $10^{1} \mathrm{cfu} /$ $\mathrm{mL}$ ) from PBS treated earlier with SDO and PMA were obtained, after which the DNA was extracted for PCR amplification. The DNA was detected individually and 


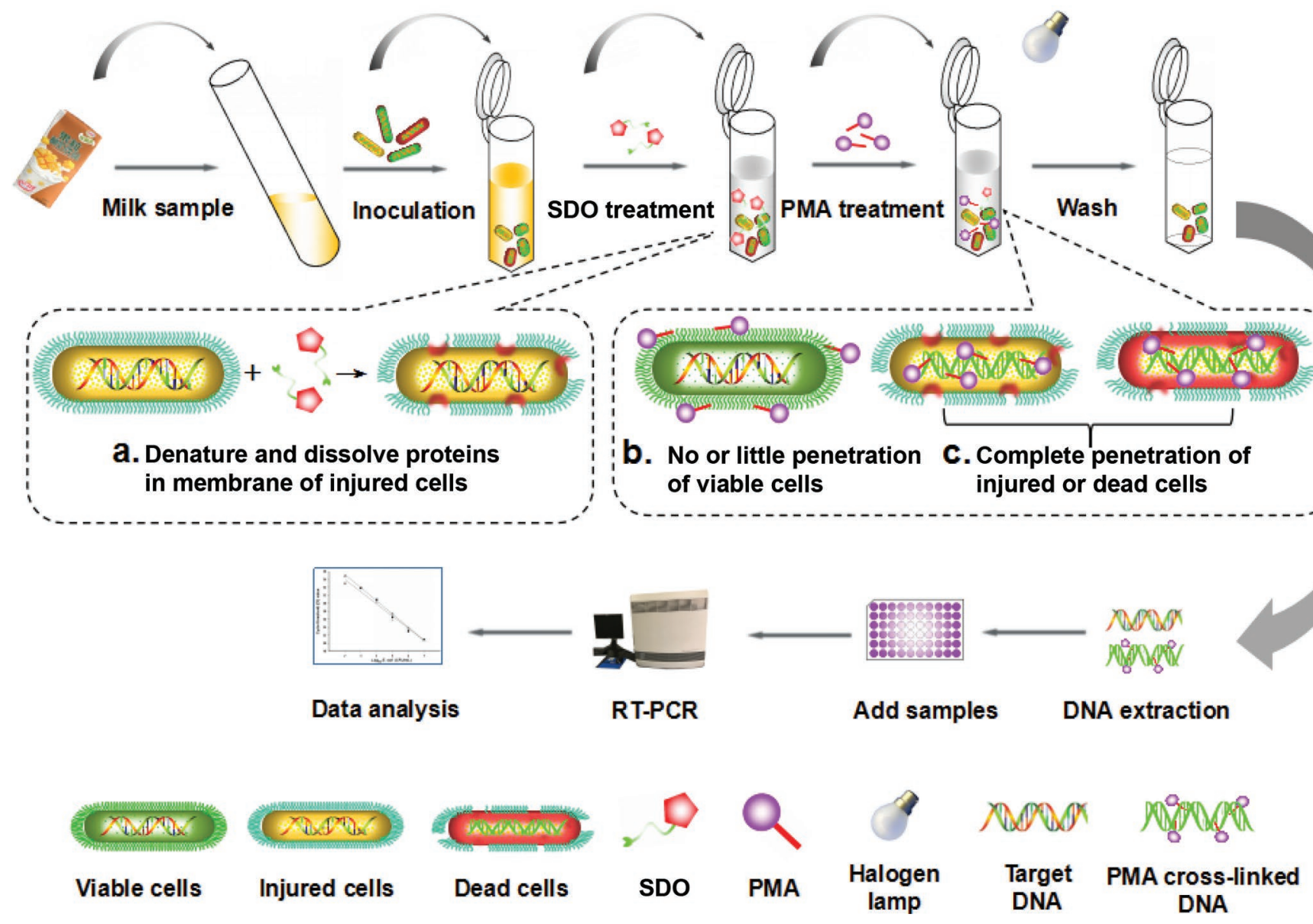

Figure 1. Overall process of sodium deoxycholate (SDO)-propidium monoazide (PMA)-multiplex real-time (RT) PCR assay for simultaneous detection of Salmonella Enteritidis and Escherichia coli O157:H7 in milk. Color version available online.

simultaneously by a mRT-PCR assay. The standard curve was generated using corresponding linear relations between target bacteria concentration and cycle threshold $(\mathbf{C t})$ value.

To determine the feasibility for enumerating of viable bacterial cells, other standard curves were obtained from bacterial DNA extracted from artificially contaminated milk. The skim milk was purchased from the Rainbow Supermarket in Nanchang, China, and tested negative for target bacteria by traditional culture methods. One milliliter of milk was mixed with $9 \mathrm{~mL}$ of PBS to form 1:10 homogenate. Then, $50 \mu \mathrm{L}$ of 10 -fold serial dilutions refresh cell suspensions were added to $450 \mu \mathrm{L}$ of produce homogenate to obtain serial dilution target bacteria (from $10^{1}$ to $10^{7} \mathrm{cfu} / \mathrm{mL}$ ). Then the suspensions were isolated by centrifugation at $12,000 \times g$ for $5 \mathrm{~min}$ at room temperature and resuspended in isometric PBS. After SDO and PMA treatment, the isolated pellets were resuspended in 100 $\mu \mathrm{L}$ of sterile water. The DNA was extracted by the water-boiling method. The treated cell suspensions were boiled for 20 min to release the DNA, and following this the supernatant containing the genomic DNA was obtained by centrifugation at $12,000 \times g$ for $3 \mathrm{~min}$ at room temperature. The obtained DNA was stored at $-20^{\circ} \mathrm{C}$. The optimum mRT-PCR system was applied to quantify the cells from artificial samples. Figure 1 shows the overall process of SDO-PMA-mRT-PCR for detection of viable E. coli O157:H7 and Salmonella spp. in artificial samples.

\section{Enumeration of Different Ratios of Viable Cells in Pure Culture by SDO-PMA-mRT-PCR Assay and Culture Method}

To determine the accuracy of the developed SDOPMA-mRT-PCR, different ratios of viable and dead cells were prepared. A different amount of viable and dead cells was added to 2 groups (5- to $500-\mu \mathrm{L}$ portions in each group) to obtain different proportions of 
viable cells $(100,75,25,10$, and $0 \%)$. One group was used for 10-fold dilutions to spread onto LB plates and incubated for $24 \mathrm{~h}$ before enumeration. The remaining groups were treated with SDO-PMA as described above. Afterward, the pellets were resuspended in 100 $\mu \mathrm{L}$ of sterile water and extracted for mRT-PCR assay.

\section{Specificity Testing in Artificial Contaminated Milk Samples}

To test whether other bacteria would interfere with the SDO-PMA-mRT-PCR assay for simultaneous detection of viable E. coli O157:H7 and Salmonella spp. in milk, 10 serial dilutions of $500 \mu \mathrm{L}$ of $E$. coli O157:H7 and Salmonella spp. ( $10^{1}$ to $\left.10^{7} \mathrm{cfu} / \mathrm{mL}\right)$ containing fresh Staphylococcus aureus $\left(10^{6} \mathrm{cfu} / \mathrm{mL}\right)$ and Cronobacter sakazakii $\left(10^{6} \mathrm{cfu} / \mathrm{mL}\right)$ were prepared. Then, the remaining operation was done as described previously.

\section{Data Analysis}

All data analyses were carried out in triplicate to prove the reproducibility of the assay. Data were analyzed for significant differences by SPSS version 19 (SPSS Inc., Chicago, IL). Results with $P<0.05$ were considered statistically significant.

\section{RESULTS}

\section{Optimization of mRT-PCR Assay}

The concentrations of the 2 target primers, 2 probes, and annealing temperature were optimized to develop the mRT-PCR assay. These results revealed that the optimized annealing temperature of mRT-PCR was $60^{\circ} \mathrm{C}$. In addition, the optimum properties of the designed primers and probes were as follows: $0.8 \mu \mathrm{L}$ for primers and $0.5 \mu \mathrm{L}$ for $\mathrm{P}-i n v A$ and $0.7 \mu \mathrm{L}$ for primers and $0.5 \mu \mathrm{L}$ for P-fliC. The optimized mRT-PCR data were obtained on the basis of $\mathrm{Ct}$ value (data not shown).

\section{Optimization Concentration of SDO}

The maximum SDO concentration without an effect on viable cells was confirmed to assess the ability of SDO to enhance penetrability to some dead and injured cells before PMA treatment was administered. In Figure $2 \mathrm{a}$, the SDO pretreatment concentration increased from 0 to $0.25 \%$ before Salmonella spp. was treated with PMA, and the $\mathrm{Ct}$ value continuously increased. At $0.25 \%$ SDO, the $\mathrm{Ct}$ value reached the highest peak, and this finding indicated that the injured and some dead cells were completely inhibited in a real-time
PCR system. At $1 \%$ SDO, Ct value was significantly reduced $(P<0.05)$. Similar results were observed in $E$. coli O157:H7 (Figure 2b). These results confirmed that $0.25 \%$ SDO was the optimized concentration that can strengthen the inhibitory effect of PMA on injured and dead cells but not on viable cells (Yang et al., 2011).

\section{Determination of the Optimal Concentration of PMA}

In this work, the optimal concentration of PMA against dead cells was determined. After 2 kinds of
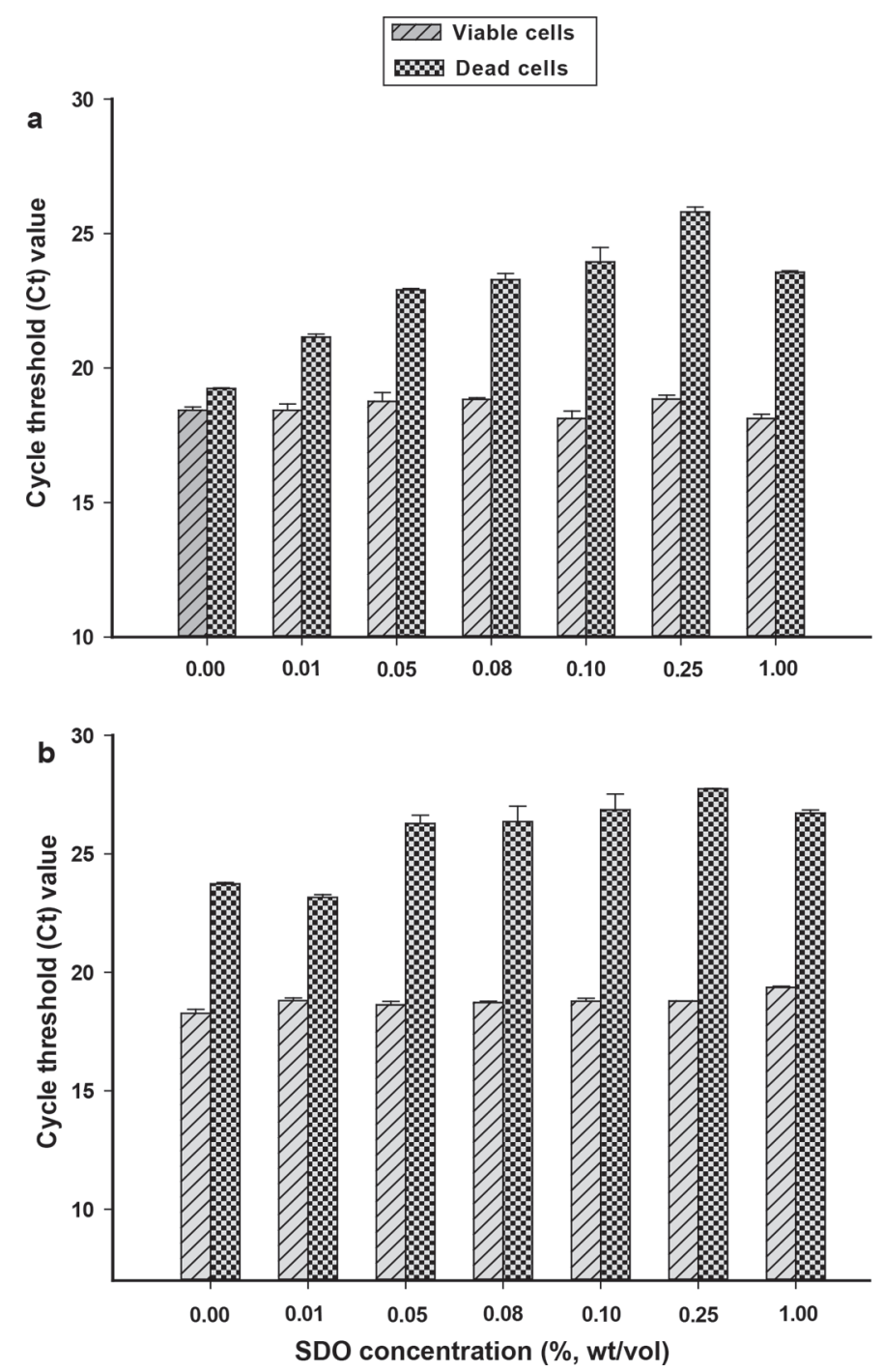

Figure 2. Optimization of the concentration of sodium deoxycholate (SDO). To reveal the effect of SDO, various cycle threshold (Ct) values were obtained by 7900 HT fast real-time PCR system (Applied Biosystems, Foster City, CA). (a) Salmonella spp. and (b) Escherichia coli $\mathrm{O} 157: \mathrm{H} 7$. Each bar represents the average $\mathrm{Ct}$ value obtained by SDO-propidium monoazide (PMA)-multiplex real-time (mRT) PCR for enumeration of target bacteria in a triplicate study. Error bars represent SD. 
target dead cells were treated with $0.25 \%$ SDO, respectively, a stepwise increase in $\mathrm{Ct}$ value was observed at 0 to $5 \mu \mathrm{g} / \mathrm{mL}$ of PMA, whereas a constant Ct value was obtained at $10 \mu \mathrm{g} / \mathrm{mL}$ of PMA (Figures $3 \mathrm{a}$ and $3 \mathrm{~b}$ ). These results demonstrated that a minimum of $5 \mu \mathrm{g} /$ $\mathrm{mL}$ of PMA was sufficiently effective to eliminate the interference from dead cells. Conversely, the $\mathrm{Ct}$ value of 2 viable cells did not significantly change at 0 to 5 $\mu \mathrm{g} / \mathrm{mL}$ of PMA $(P>0.05)$. The $\mathrm{Ct}$ values of viable
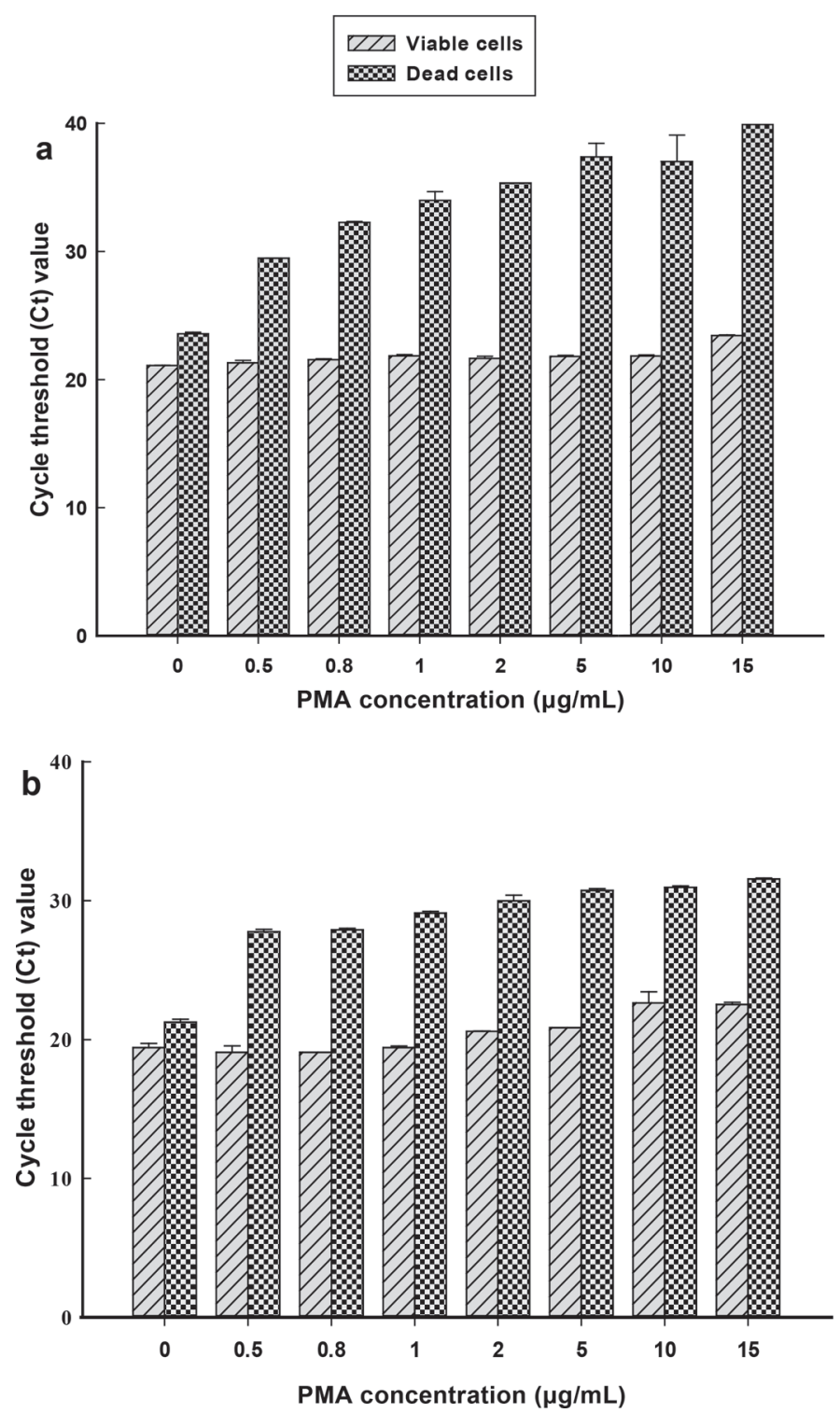

Figure 3. Optimization of the concentration of propidium monoazide (PMA). The effect of PMA was revealed by different cycle threshold (Ct) values from 7900HT fast real-time PCR system (Applied Biosystems, Foster City, CA). (a) Salmonella spp. and (b) Escherichia coli O157:H7. Each bar represents the average Ct value obtained by sodium deoxycholate-PMA-multiplex real-time (mRT) PCR for enumeration of target bacteria in a triplicate study. Error bars represent SD.
Salmonella spp. and viable E. coli O157:H7 evidently increased at 15 and $10 \mu \mathrm{g} / \mathrm{mL}$ of PMA, respectively $(P<0.05)$. These results suggested that a maximum of $5 \mu \mathrm{g} / \mathrm{mL}$ of PMA did not affect these viable cells. Considering the effect of PMA on dead and viable cells, we used $5 \mu \mathrm{g} / \mathrm{mL}$ as the final optimized PMA concentration to inhibit the interference of dead cells on viable cells.

\section{Standard Curves of Pure Culture and Artificial Contaminated Samples}

The standard curve was established by the optimized SDO-PMA-mRT-PCR assay to quantify viable Salmonella spp. and E. coli O157:H7. In Figures 4a and 4b, the target bacteria were detected through mRT-PCR, and 2 standard curves showed an ideal linear correlation: $\mathrm{R}^{2}=0.9981$ for Salmonella spp. and $\mathrm{R}^{2}=0.9957$ for $E$. coli O157:H7. The LOD were $10^{2} \mathrm{cfu} / \mathrm{mL}$ for Salmonella spp. and $10^{2} \mathrm{cfu} / \mathrm{mL}$ for E. coli O157:H7.

The standard curve of artificial contaminated milk was also established to determine the practicability of this assay. In Figure $4 \mathrm{a}$ and 4b, 2 standard curves revealed an ideal linear correlation: $\mathrm{R}^{2}=0.9689$ for Salmonella spp. and $\mathrm{R}^{2}=0.9993$ for E. coli O157:H7. The LOD of the assay in artificial contaminated milk were $10^{2} \mathrm{cfu} / \mathrm{mL}$ for Salmonella spp. and $10^{2} \mathrm{cfu} / \mathrm{mL}$ for E. coli O157:H7. The LOD of pure culture did not significantly differ from that of artificial contaminated milk $(P>0.05)$. Thus, the developed assay could be applied to detect the 2 target bacterial strains without the interference of the food matrix.

\section{Accuracy of the SDO-PMA-mRT-PCR Assay at Different Ratios of Viable Cells}

Different ratios of viable cells were prepared to detect the bacterial strains through the SDO-PMAmRT-PCR assay and to determine the accuracy of this assay. In Figure 5a, the number of viable Salmonella spp. obtained through the SDO-PMA-mRT-PCR assay was not significantly different from that determined through the traditional culture method $(P>0.05)$. A similar result was observed in the detected $E$. coli O157:H7 (Figure 5b). These results confirmed that SDO-PMA-mRT-PCR could accurately detect viable target bacteria.

\section{Specificity of the SDO-PMA-mRT-PCR Assay}

The specificity of the primers was initially evaluated (Table 1), and these results indicated that only target bacterial strains (Salmonella spp. and E. coli O157:H7) could display a positive signal. The specificity of the 

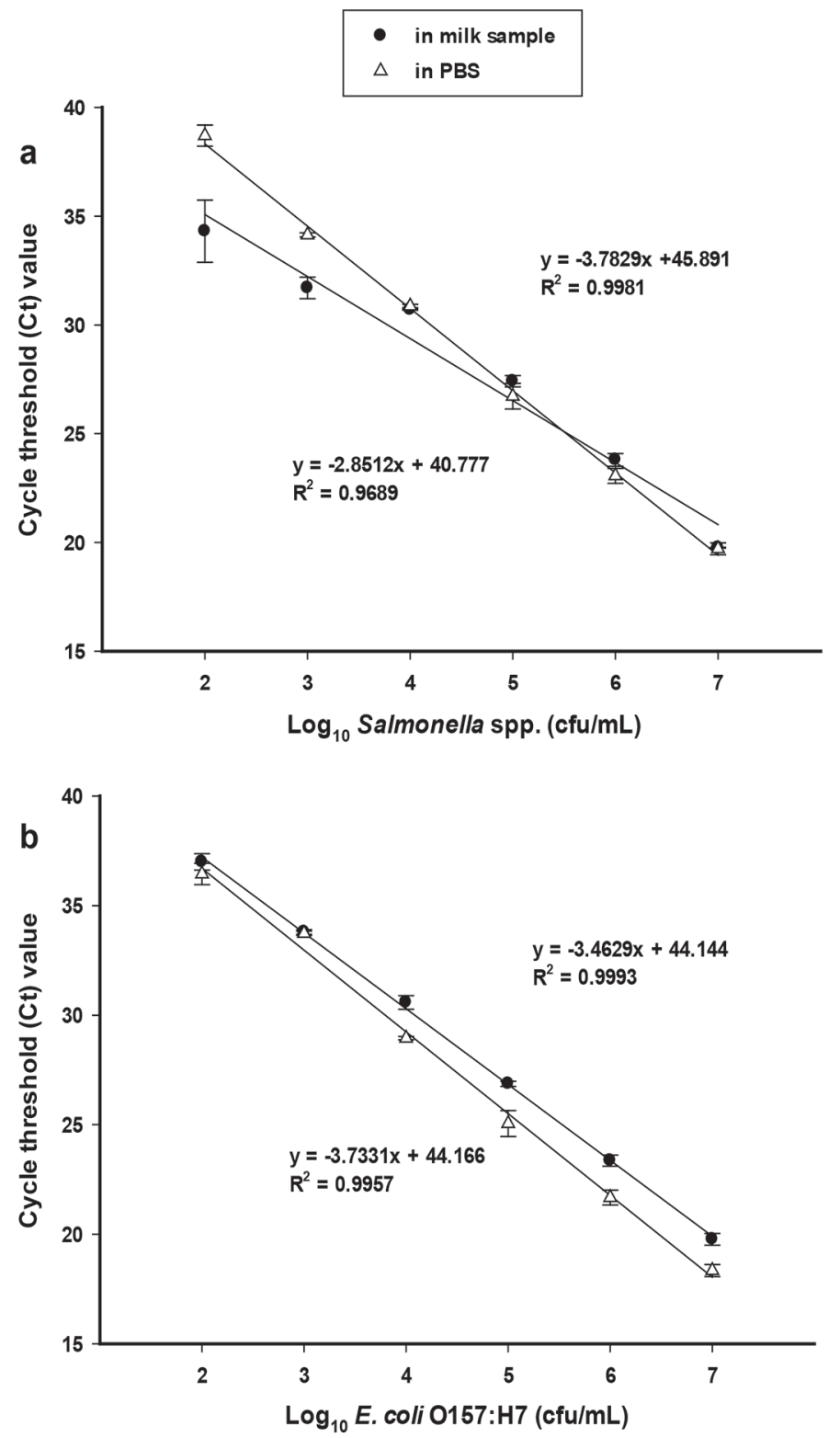

Figure 4. Establishment of standard curves for sodium deoxycholate (SDO)-propidium monoazide (PMA)-multiplex real-time (mRT)PCR. Standard curves for Salmonella spp. (a) and Escherichia coli O157:H7 (b) in PBS $(\Delta)$ and the milk sample $(\bullet)$. Each data point represents the average cycle threshold $(\mathrm{Ct})$ value of triplicate assays plotted against the number of viable cells per milliliter for each matrix. Error bars represent SD.

assay was then estimated in the presence of $S$. aureus $\left(10^{6} \mathrm{cfu} / \mathrm{mL}\right)$ and C. sakazakii $\left(10^{6} \mathrm{cfu} / \mathrm{mL}\right)$ in the artificial contaminated samples. In Figure 6a, the Ct value and LOD from detection of different concentrations of viable Salmonella spp. did not significantly differ in the presence or absence of $S$. aureus and C. sakazakii ( $P$ $>0.05)$. Similar results were obtained in the detection of E. coli O157:H7. These results implied that the developed SDO-PMA-mRT-PCR assay could be sensi-
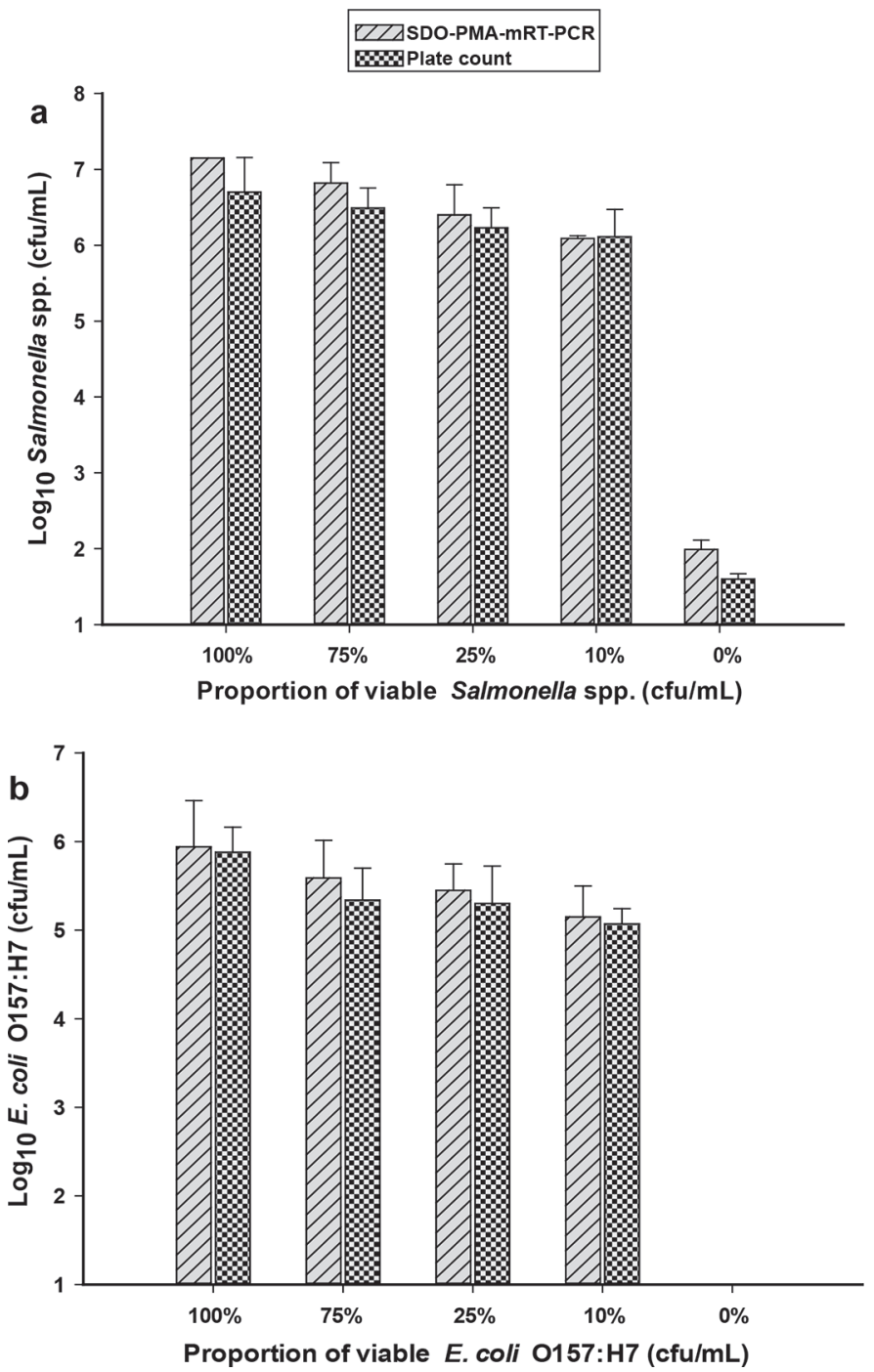

Figure 5. Enumeration of different ratios of viable cells of 2 target bacteria by using the sodium deoxycholate (SDO)-propidium monoazide (PMA)-multiplex real-time (mRT)-PCR and plate count method in PBS. (a) Salmonella spp. and (b) Escherichia coli O157:H7. All enumerations of this assay for detection of viable cells were obtained from the standard curve in PBS. Each bar represents the average number of viable cells enumerated by SDO-PMA-mRT-PCR in a triplicate study. Error bars represent SD.

tive and could specifically detect the 2 target bacterial strains without the interference of nontarget bacteria.

\section{DISCUSSION}

Multiplex PCR has been used as an effective tool to quantify Salmonella spp. and E. coli O157:H7 because of its advantages, such as time savings, low cost, and easy operation (Truchado et al., 2016; Kibbee and Örmeci, 2017). However, mPCR assays have failed to fully distinguish among viable, dead, and injured bacteria (Nkuipou-Kenfack et al., 2013; Zhou et al., 2016). A 

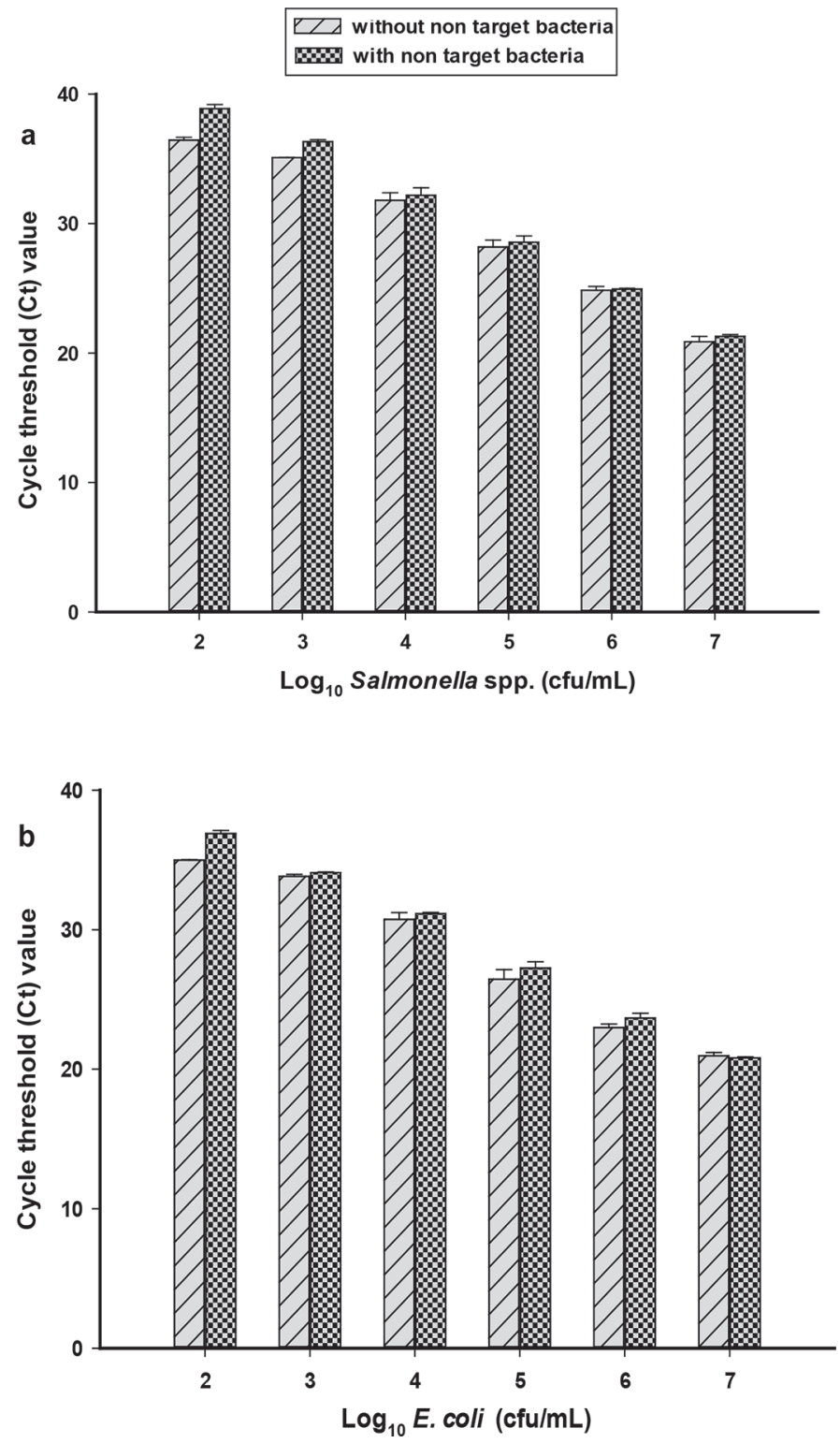

Figure 6. The enumeration of 2 target bacteria by standard curves in presence of nontarget bacteria of $10^{6} \mathrm{cfu} / \mathrm{mL}$. (a) Salmonella spp. and (b) Escherichia coli O157:H7. Each bar represents the average cycle threshold $(\mathrm{Ct})$ value obtained by sodium deoxycholate-propidium monoazide-multiplex real-time PCR for enumeration of target bacteria in a triplicate study. Error bars represent SD.

previous research demonstrated that an SDO pretreatment combined with PMA is an effective method to observe viable cells only (Wang et al., 2014b). In our study, an effective SDO-PMA-mRT-PCR assay was developed to detect viable Salmonella spp. and E. coli O157:H7 simultaneously in milk. This assay could efficiently eliminate the interference of dead and injured cells and could accurately and sensitively detect these bacterial cells in spiked milk.
In some reports, injured cells remain dormant under regular conditions, but their activity can be recovered under complicated and nutrient-rich conditions. Injured cells cannot infect and harm their hosts under normal conditions (Morgan et al., 1993). Thus, the inhibition of injured cells during detection is meaningful. As a DNA-binding dye, PMA is widely used to distinguish viable cells from dead and injured cells effectively in a detection system. However, PMA treatment fails to inhibit dead and injured cells completely because of the barrier properties of their integrated outer membrane. To solve this problem and enhance the effect of PMA, we applied an SDO pretreatment. The effects of SDO on dead and injured cells are based on its emulsifying properties, which can bind some proteins and lipids in the cell membrane to destroy their membrane structure. A specific amount of SDO cannot prevent the vitality of viable cells. The optimal concentrations of $0.25 \%$ SDO and $5 \mu \mathrm{g} / \mathrm{mL}$ of PMA were selected. The dosage of PMA treatment was less than that in previous studies (Li et al., 2017a) mainly because an SDO pretreatment could improve the utilization rate of PMA and low initial target bacterial concentrations were selected to optimize the mRT-PCR detection system.

Primers and probes are the key point to ensure sensitive, specific, and simultaneous detection through mRT-PCR. In this study, a 127-bp fragment of primers and a 24-bp fragment of a probe from fliC of $E$. coli O157:H7 and a 95-bp fragment of primers and a 24-bp fragment of a probe from invA of Salmonella spp. were selected for the specific amplification. Previous studies involved the use of fliC of E. coli $\mathrm{O} 157: \mathrm{H} 7$ and invA of Salmonella spp. for specific detection. Conversely, the primers and probes were designed by the authors, and this study is a new application to combine these primers and probes with SDO-PMA-mRT-PCR for the detection of viable E. coli O157:H7 and Salmonella spp. in milk. The specificity of the primers was confirmed by using 30 strains.

The LOD is an important parameter in evaluating the feasibility and practicability of detection methods. Under normal conditions, pre-enrichment and immunomagnetic separation are frequently used to enrich target bacteria and improve LOD. Wang et al. (2014a) used an immunomagnetic separation assay for $E$. coli O157:H7 enrichment, and the LOD of this assay is $10^{2}$ $\mathrm{cfu} / \mathrm{mL}$. Li et al. (2017b) applied a 12-h pre-enrichment for Salmonella Enteritidis, and the LOD of this assay is $10^{2} \mathrm{cfu} / \mathrm{mL}$ in spiked vegetables. In our work, 2 primers and probes were demonstrated with an ideal amplification efficiency and optimized mPCR parameters, where LOD were $10^{2} \mathrm{cfu} / \mathrm{mL}$ for Salmonella spp. and $10^{2} \mathrm{cfu} /$ $\mathrm{mL}$ for E. coli O157:H7 in pure culture. Similar results 
could be obtained in spiked milk. Our proposed method saves more time and is more accurate than a regular mPCR assay for the detection of multiplex bacteria. In addition, this assay exhibited high specificity and exclusivity and thus could be applied to detect Salmonella spp. and E. coli O157:H7 specifically without interference from nontarget bacteria.

\section{CONCLUSIONS}

In this study, a new mRT-PCR combined with SDO and PMA was developed to detect viable Salmonella spp. and E. coli O157:H7 simultaneously and sensitively in milk. The primers and probes were designed to ensure the specificity of this assay and to avoid interference from food matrix and nontarget bacteria. This assay could quantify the detected viable cells without interference from dead and injured cells in milk. The optimized assay could reveal $10^{2} \mathrm{cfu} / \mathrm{mL}$ of Salmonella spp. and $10^{2} \mathrm{cfu} / \mathrm{mL}$ of E. coli $\mathrm{O} 157: \mathrm{H} 7$ in milk. Therefore, the developed SDO-PMA-mRT-PCR method is a valuable diagnostic tool to detect viable $E$. coli O157:H7 and Salmonella spp. in milk.

\section{ACKNOWLEDGMENTS}

The work was supported by the Research Foundation for Young Scientists of State Key Laboratory of Food Science and Technology, Nanchang University, China (No. SKLF-QN-201504).

\section{REFERENCES}

Alves, J., E. Y. Hirooka, and T. C. R. M. de Oliveira. 2016. Development of a multiplex real-time PCR assay with an internal amplification control for the detection of Campylobacter spp. and Salmonella spp. in chicken meat. Lebensm. Wiss. Technol. 72:175-181.

Amagliani, G., A. Petruzzelli, E. Carloni, F. Tonucci, M. Foglini, E. Micci, M. Ricci, S. Di Lullo, L. Rotundo, and G. Brandi. 2016. Presence of Escherichia coli O157, Salmonella spp., and Listeria monocytogenes in raw ovine milk destined for cheese production and evaluation of the equivalence between the analytical methods applied. Foodborne Pathog. Dis. 13:626-632.

Andrews-Polymenis, H. L., A. J. Bäumler, B. A. McCormick, and F. C. Fang. 2010. Taming the elephant: Salmonella biology, pathogenesis, and prevention. Infect. Immun. 78:2356-2369.

Angulo, F. J., J. T. LeJeune, and P. J. Rajala-Schultz. 2009. Unpasteurized milk: A continued public health threat. Clin. Infect. Dis. 48:93-100.

Arroyo, C., S. Condon, and R. Pagan. 2009. Thermobacteriological characterization of Enterobacter sakazakii. Int. J. Food Microbiol. 136:110-118.

Costard, S., L. Espejo, H. Groenendaal, and F. J. Zagmutt. 2017. Outbreak-related disease burden associated with consumption of unpasteurized cow's milk and cheese, United States, 2009-2014. Vol. 23. June 2017. Accessed Jul. 11, 2017. https://wwwnc.cdc .gov/eid/article/23/6/15-1603-t1.

Elizaquível, P., J. Gabaldón, and R. Aznar. 2011. Quantification of Salmonella spp., Listeria monocytogenes and Escherichia coli
O157: H7 in non-spiked food products and evaluation of real-time PCR as a diagnostic tool in routine food analysis. Food Contr. 22:158-164.

Garrido, A., M.-J. Chapela, B. Román, P. Fajardo, J. Lago, J. M. Vieites, and A. G. Cabado. 2013. A new multiplex real-time PCR developed method for Salmonella spp. and Listeria monocytogenes detection in food and environmental samples. Food Contr. 30:7685.

Karmali, M. A. 1989. Infection by verocytotoxin-producing Escherichia coli. Clin. Microbiol. Rev. 2:15-38.

Kibbee, R. J., and B. Örmeci. 2017. Development of a sensitive and false-positive free PMA-qPCR viability assay to quantify VBNC Escherichia coli and evaluate disinfection performance in wastewater effluent. J. Microbiol. Methods 132:139-147.

Kim, H., and A. K. Bhunia. 2008. SEL, a selective enrichment broth for simultaneous growth of Salmonella enterica, Escherichia coli O157: H7, and Listeria monocytogenes. Appl. Environ. Microbiol. 74:4853-4866.

Lee, N., K. Y. Kwon, S. K. Oh, H.-J. Chang, H. S. Chun, and S.-W. Choi. 2014. A multiplex PCR assay for simultaneous detection of Escherichia coli O157: H7, Bacillus cereus, Vibrio parahaemolyticus, Salmonella spp., Listeria monocytogenes, and Staphylococcus aureus in Korean ready-to-eat food. Foodborne Pathog. Dis. 11:574-580.

Li, F., B. Li, H. Dang, Q. Kang, L. Yang, Y. Wang, Z. P. Aguilar, W. Lai, and H. Xu. 2017a. Viable pathogens detection in fresh vegetables by quadruplex PCR. Lebensm. Wiss. Technol. 81:306-313.

Li, F., F. Li, B. Chen, B. Zhou, P. Yu, S. Yu, W. Lai, and H. Xu. 2017b. Sextuplex PCR combined with immunomagnetic separation and PMA treatment for rapid detection and specific identification of viable Salmonella spp., Salmonella enterica serovars Paratyphi B, Salmonella Typhimurium, and Salmonella Enteritidis in raw meat. Food Contr. 73:587-594.

Li, F., G. Xie, B. Zhou, P. Yu, S. Yu, Z. P. Aguilar, H. Wei, and H. Xu. 2016. Rapid and simultaneous detection of viable Cronobacter sakazakii, Staphylococcus aureus, and Bacillus cereus in infant food products by PMA-mPCR assay with internal amplification control. Lebensm. Wiss. Technol. 74:176-182.

Linder, K., and J. D. Oliver. 1989. Membrane fatty acid and virulence changes in the viable but nonculturable state of Vibrio vulnificus. Appl. Environ. Microbiol. 55:2837-2842.

Ma, K., Y. Deng, Y. Bai, D. Xu, E. Chen, H. Wu, B. Li, and L. Gao. 2014. Rapid and simultaneous detection of Salmonella, Shigella, and Staphylococcus aureus in fresh pork using a multiplex real-time PCR assay based on immunomagnetic separation. Food Contr. 42:87-93.

Mackay, I. M. 2004. Real-time PCR in the microbiology laboratory. Clin. Microbiol. Infect. 10:190-212.

Morgan, J., G. Rhodes, and R. Pickup. 1993. Survival of nonculturable Aeromonas salmonicida in lake water. Appl. Environ. Microbiol. $59: 874-880$.

Munsi, M. N., N. R. Sarker, R. Khatun, and M. K. Alam. 2016. Identification and antibiogram study of bacterial species isolated from milk samples of different locations in Bangladesh. Asian J. Med. Biol. Res. 1:457-462.

Nataro, J. P., and J. B. Kaper. 1998. Diarrheagenic Escherichia coli. Clin. Microbiol. Rev. 11:142-201.

Nkuipou-Kenfack, E., H. Engel, S. Fakih, and A. Nocker. 2013. Improving efficiency of viability-PCR for selective detection of live cells. J. Microbiol. Methods 93:20-24.

Omiccioli, E., G. Amagliani, G. Brandi, and M. Magnani. 2009. A new platform for Real-Time PCR detection of Salmonella spp., Listeria monocytogenes and Escherichia coli $\mathrm{O} 157$ in milk. Food Microbiol. 26:615-622.

Paton, J. C., and A. W. Paton. 1998. Pathogenesis and diagnosis of Shiga toxin-producing Escherichia coli infections. Clin. Microbiol. Rev. 11:450-479.

Ran, L., S. Wu, Y. Gao, X. Zhang, Z. Feng, Z. Wang, B. Kan, J. D. Klena, D. M. Lo Fo Wong, and F. J. Angulo. 2011. Laboratorybased surveillance of nontyphoidal Salmonella infections in China. Foodborne Pathog. Dis. 8:921-927. 
Truchado, P., M. I. Gil, T. Kostic, and A. Allende. 2016. Optimization and validation of a PMA qPCR method for Escherichia coli quantification in primary production. Food Contr. 62:150-156.

Wang, H., C. O. Gill, and X. Yang. 2014a. Use of sodium lauroyl sarcosinate (sarkosyl) in viable real-time PCR for enumeration of Escherichia coli. J. Microbiol. Methods 98:89-93.

Wang, J., R. Li, L. Hu, X. Sun, J. Wang, and J. Li. 2016. Development of a quantitative fluorescence single primer isothermal amplification-based method for the detection of Salmonella. Int. J. Food Microbiol. 219:22-27.

Wang, L., P. Li, Z. Zhang, Q. Chen, Z. P. Aguilar, H. Xu, L. Yang, F. Xu, W. Lai, and Y. Xiong. 2014b. Rapid and accurate detection of viable Escherichia coli O157: H7 in milk using a combined IMS, sodium deoxycholate, PMA and real-time quantitative PCR process. Food Contr. 36:119-125.

Wang, L., C. Ye, H. Xu, Z. P. Aguilar, Y. Xiong, W. Lai, and H. Wei. 2015. Development of an SD-PMA-mPCR assay with internal amplification control for rapid and sensitive detection of viable Salmonella spp., Shigella spp. and Staphylococcus aureus in food products. Food Contr. 57:314-320.
Wang, R. F., W. W. Cao, and C. Cerniglia. 1997. A universal protocol for PCR detection of 13 species of foodborne pathogens in foods. J. Appl. Microbiol. 83:727-736.

Wang, X., C. Zhu, X. Xu, and G. Zhou. 2012. Real-time PCR with internal amplification control for the detection of Cronobacter spp. (Enterobacter sakazakii) in food samples. Food Contr. 25:144-149.

Yang, X., M. Badoni, and C. O. Gill. 2011. Use of propidium monoazide and quantitative PCR for differentiation of viable Escherichia coli from E. coli killed by mild or pasteurizing heat treatments. Food Microbiol. 28:1478-1482.

Zhang, Z., L. Xiao, Y. Lou, M. Jin, C. Liao, P. K. Malakar, Y. Pan, and Y. Zhao. 2015. Development of a multiplex real-time PCR method for simultaneous detection of Vibrio parahaemolyticus, Listeria monocytogenes and Salmonella spp. in raw shrimp. Food Contr. 51:31-36.

Zhou, B., B. Chen, X. Wu, F. Li, P. Yu, Z. P. Aguilar, H. Wei, and H. $\mathrm{Xu}$. 2016. A new application of a sodium deoxycholate-propidium monoazide-quantitative PCR assay for rapid and sensitive detection of viable Cronobacter sakazakii in powdered infant formula. J. Dairy Sci. 99:9550-9559. 